\title{
Product-service system method to measure sustainability level of traditional smoked fish processing industries
}

\author{
Ratna Purwaningsih ${ }^{1 *}$, Anggaina Elfandora Cahyantari ${ }^{1}$, Zulfaida Ariyani ${ }^{2}$, Aries Susanty ${ }^{1}$, Ary Arvianto $^{1}$, and Haryo \\ Santoso ${ }^{1}$ \\ ${ }^{1}$ Diponegoro University, Industrial Engineering Department, Jl Prof Soedharto SH, Tembalang, Semarang, 50275, Indonesia \\ ${ }^{2}$ Diponegoro University, Vocational School, Jl Prof Soedharto SH, Tembalang, Semarang, 50275, Indonesia
}

\begin{abstract}
Small Medium Enterprise's (SME) of traditional fish processing at Semarang, Central Java, Indonesia still focus their business on gain more profits. Sustainability aspect has not received enough attention yet. This study aims to review the sustainability level of SME smoked fish Semarang using product service system (PSS) method. PSS consists of three dimensions (1) Environment, (2) Socio-cultural and (3) Economic. Each dimension consists of 6 criteria's. PSS not only assess the level of sustainability but also formulated the recommendation to increase the industries sustainability level. Sustainability assessment and recommendations formulation is guided by a check-list form. Then, the portfolio diagram used to select these recommendations according to its feasibility to be implemented and its importance for the industries. The result of sustainability assessment for traditional fish processing is 0.44 , categorized as medium level. The recommendations for the environmental dimension are (1) use of liquid smoke on fish processing and (2) use of wastewater treatment with anaerobic ponds Recommendation for the socio-cultural dimension is use personal protective tool to reduce worker risk on safety and health. Recommendation for the economic dimension is used social media for product marketing and increasing the economic value of fish lung wastes. Recommendations are then illustrated in a diagram in the form of radar sustainability.
\end{abstract}

\section{Introduction}

Sustainable development has been defined in many ways, but the most frequently quoted definition is from Brundtland Report: "Sustainable development is the development that meets the needs of the present without compromising the ability of future generations to meet their own needs [1]. Product-service system (PSS) is a method to measure industry sustainability level. There are three dimensions of sustainability that will be the basis for assessing and formulating recommendations to increase sustainability level. These three dimensions are the environmental, socio-cultural and economic dimensions in which each dimension contains six criteria [2]. Application of PSS in the industry was believed to be a source of innovation [3], improving consumer satisfaction, product life-cycle management and information flow in the manufacturing cycle [4], also increase company productivity levels [5].

Assessment of the sustainability level of a region or a business unit has been developed in various fields. Sustainability indicator on mining and mineral sectors was developed by MMSD (Mining, Minerals and Sustainable Development). In the forestry sector, the impact assessment of the forest wood supply chain is measured using ToSIA / A Tool for Sustainability Impact Assessment [6]. In the chemical sector the characterization factors for human eco-toxicity and toxicity were measured by the Uniform System for the Evaluation of Substance or USES-LCA) method [7]. In industry has been developed a measurement method and indicators of Sustainable Development for Industry (ISDI). Sustainability is assessed through environmental impact, environmental efficiency, and voluntary action. ISDI follows the lifecycle approach and considers the complete life cycle of materials and energy utilized [8].

There has been a significant decrease which reaches $48 \%$ in production volume of SME smoked fish at Semarang. Although, the raw material for the production of smoke fish was increased by $14 \%$, and fish consumption of Semarang community increased at $15 \%$ [9]. Besides, there are environmental and health problems of workers and the surrounding community due to the smoke from the fish processing. The smoke that arises during the production process contains chemicals that potential to cause a decline in lung function and threaten the health of workers. The surrounding community is also disturbed by the pollution. Worker health problems and their impact on surrounding communities are included in the problems of the socio-cultural dimension [10]. The purpose of this study is to measure the sustainability level, formulate recommendations and assess the recommendations.

Since 1970, marketing and innovation management have been trying to find ways to connect the functions of consumer desires into new product and service design systems. PSS is one method that connects various stakeholders in the design and assessment, as well as system development both production system and in product and service development. The global green

* Corresponding author: ratna.tiundip@gmail.com 
economic transition calls for the transformation of business strategy from traditional business-oriented model to service-oriented business model. One of the new business models that fit this transformation is the product -service system [11]. Geum and Park [12] created a road map of PSS in the form of a systematic methodology for PSS to be easily applied.

Application of Product Service System in System Design is on the design of supply chain. Wang and Fu Jia [13] applied PSS to develop a supply chain that considers multi-stakeholders. Wangphanich [14] examines the impact of applying PSS to the supply chain of a washing machine product to a dynamic system simulation and found that PSS can reduce the environmental impact of the product to consumers. Durugbo [15] combines PSS with Collaborative Networks on a product delivery system. Application of PSS in logistic system design done by Xing and Heon Lee [16] they used PSS to design logistic system and combine it with life cycle model approach.

\section{Research Method}

PSS method is carried out in a series of stages developed by UNEP and DELFT University of Technology. PSS consists of 4 stages (1) Identify system sustainability dimension, (2) Formulate and select recommendation, (3) Conduct assessment of detail of recommendation, and (4) Conduct feasibility test on a recommendation to choose the best one. The first stage is to identify the dimensions of system sustainability. There are 3 activities in this stage, drawing system maps, making a SWOT of sustainability and assessing system sustainability.

The second stage is to formulate and select recommendations. At this stage, the questionnaire was distributed using the PSS worksheet. The results of the questionnaire are then used to make detailed recommendations. The recommendation categorize on 4 class; $\mathrm{H}=$ high, $\mathrm{M}=$ Medium, $\mathrm{L}=$ Low and $\mathrm{N}=\mathrm{No}$, or have no relation. The recommendation will be detailed are the $\mathrm{H}$ categorize.

The third stage is to choose the recommendations to be applied. At this stage, the recommendations selected in stage 2 are then detailed. We assess the recommendation by giving the 'mark' ++ for much better, + for better, $=$ for nothing change and - mean worse than existing condition. This mark then became the-y axis value of sustainability improvement possibility in portfolio diagram. The fourth stage is to test the feasibility of recommendations by making portfolio diagrams and PSS radar. Radar serves to compare the future conditions if the recommendation applied to the current system. Then, we need to create a portfolio diagram use a feasibility recommendation questionnaire. Respondents were asked to assess detailed recommendations with judgment based considerations, (a) Duration of recommendations (long term or short term), and (b) Easy-ness of implementation/ implementation (difficult to implement, or easy to implement). This feasibility value became the value of the $\mathrm{x}$-axis on portfolio diagram. This portfolio diagram has the $y$-axis for sustainability improvement possibility and the $\mathrm{x}$-axis for feasibility/ implementation. Put all recommendations in the matrix according to its value on these two dimensions.

\section{Results and Discussion}

The sustainability assessment was given to 21 traditional smoked fish processing at Bandarhardjo Semarang. The system map and sustainability SWOT were done by interviewing the owner of traditional fish processing industries and related agencies. The result of system map given in figure 1 and sustainability SWOT in detail given in table 1. This SWOT analysis will be useful in identifying recommendation for sustainability improvement.

- Fish Landing/ raw material : Juwana, Rembang, Cilacap, Madura

- Coconut shell as a fuel

- Ground water for production process and clean the equipment

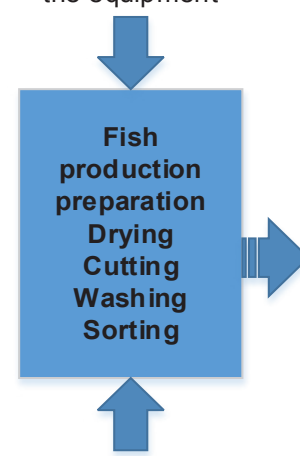

- Tawas for soaking and washing of raw materials

- Production equpment supplier

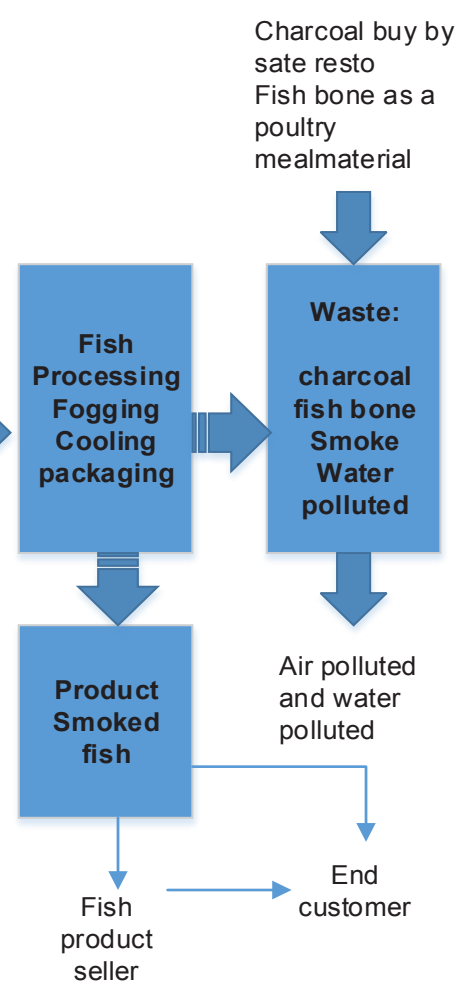

Fig. 1. System map of traditional smoked fish processing industries

Figure 1 shows the parties involved in the smoked fish production. Related parties include fresh fish suppliers, coconut shell suppliers, processed fish traders, waste collectors, and consumers. The system begins when the industry owner purchase of fish as raw materials in the fish market. The amount or the availability of raw material was following the natural conditions. The fuel (the coconut shell) purchased from coconut shell collectors who came to the traditional fish processing center. The raw materials obtained on one day then processed entirely on the same day. Smoked fish are immediately distributed on the same day to traders in the market, or to consumers who come directly to the industries location. The wastes are partially sold, and some are still poorly managed. 
Table 1. Result of SWOT sustainability analysis

\begin{tabular}{|c|c|c|}
\hline \multirow{2}{*}{ SW } & \multicolumn{2}{|c|}{ State the existing condition } \\
\hline & Strength & Weakness \\
\hline 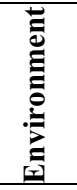 & $\begin{array}{l}\text { Several types of } \\
\text { waste have been re- } \\
\text { utilized } \\
\text { There is waste has a } \\
\text { high selling value } \\
\end{array}$ & $\begin{array}{l}\text { The production process } \\
\text { is traditional. } \\
\text { The result of polluted } \\
\text { waste. } \\
\text { Poor water quality }\end{array}$ \\
\hline 莺 & $\begin{array}{l}\text { The industry in } \\
\text { Bandarharjo has been } \\
\text { established for almost } \\
\text { half a century }\end{array}$ & $\begin{array}{l}\text { Health and safety risks } \\
\text { Air pollution disturb the } \\
\text { community } \\
\text { Not hygienist process } \\
\text { Low-level education }\end{array}$ \\
\hline 弟 & $\begin{array}{l}\text { economic support } \\
\text { from the government }\end{array}$ & $\begin{array}{l}\text { Products (potentially } \\
\text { containing bacteria and } \\
\text { carcinogenic } \\
\text { substances) }\end{array}$ \\
\hline \multicolumn{3}{|c|}{ State of future condition } \\
\hline OT & Opportunity & Threat \\
\hline 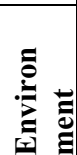 & $\begin{array}{l}\text { Liquid curing } \\
\text { techniques to reduce } \\
\text { air pollution and } \\
\text { carcinogenic }\end{array}$ & $\begin{array}{l}\text { Long-term } \\
\text { environmental } \\
\text { degradation. }\end{array}$ \\
\hline 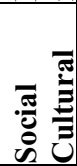 & $\begin{array}{l}\text { Future generations } \\
\text { who are educated can } \\
\text { change to better } \\
\text { production process }\end{array}$ & $\begin{array}{l}\text { The health of workers is } \\
\text { threatened. } \\
\text { Poor quality of the } \\
\text { production environment }\end{array}$ \\
\hline 蒫 & $\begin{array}{l}\text { The culinary tourism } \\
\text { Further waste } \\
\text { treatment }\end{array}$ & $\begin{array}{l}\text { Competition that is not } \\
\text { addressed properly will } \\
\text { threaten the existence of } \\
\text { industries }\end{array}$ \\
\hline
\end{tabular}

Next step is the categorization of sustainability criteria. This step is conducted to find out what sustainability criteria need to be developed by giving the categorization as No, Low, Medium or High categories. Categorization of criteria conducted after the spreading of questionnaires to 21 fish processing industries. Then, the average calculation of all criteria was scored [17]. Results of calculation found that the level of sustainability of smoked fish industries of Semarang City is 0.44. It indicates that the sustainability of the industries center is in the medium class. The sustainability assessment results were given in table 2 .

The third step is the formulation the recommendations, obtained from the results of the questionnaires referring to the Recommendation Development Guide. Questionnaires were distributed to 23 academicians, 2 industries practitioners, and 3 industry and trade ministry officer of Semarang district. The recommendation coding is given in table 3 .

Table 2. Result of sustainability assessment

\begin{tabular}{|l|l|l|l|}
\hline & \multicolumn{1}{|c|}{ Criteria's } & \multicolumn{1}{c|}{ Score } & Categorize \\
\hline \multirow{2}{*}{} & System Age Optimization & 0.36 & Medium \\
\cline { 2 - 4 } & Reduction of Transportation / & 0.09 & Low \\
\cline { 2 - 4 } & Reduction of Resources & 0.11 & Low \\
\cline { 2 - 4 } & $\begin{array}{l}\text { Minimization / Waste } \\
\text { Management }\end{array}$ & 1 & High \\
\cline { 2 - 4 } & Conservation & 0 & No \\
\cline { 2 - 4 } & Toxicity & 0.5 & Medium \\
\hline
\end{tabular}

\begin{tabular}{|c|c|c|c|}
\hline \multirow{5}{*}{ 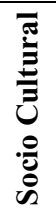 } & Social Responsibility & 0 & No \\
\hline & Occupational Health and & 1 & High \\
\hline & Product quality & 0.28 & Low \\
\hline & Employment & 0.38 & Medium \\
\hline & Stakeholders relationship & 0.5 & Medium \\
\hline \multirow{6}{*}{ 象 } & $\begin{array}{l}\text { Market position and } \\
\text { competitiveness }\end{array}$ & 0.9 & High \\
\hline & Profitability & 1 & High \\
\hline & Value-added for consumers & 0.33 & Low \\
\hline & Long-Term Risk & 0.7 & High \\
\hline & Partnership / Cooperation & 0.4 & Medium \\
\hline & Macroeconomic Effect & 0 & No \\
\hline \multicolumn{2}{|c|}{ Mean } & 0.44 & Medium \\
\hline
\end{tabular}

Table 3. Alternative recommendation

\begin{tabular}{ll}
\hline \multicolumn{1}{c}{ Criteria } & \multicolumn{1}{c}{ Alternative Recommendation } \\
\hline $\begin{array}{l}\text { A. Minimization } \\
\text { Management }\end{array}$ & $\begin{array}{l}\text { A.1. Using liquid smoke } \\
\text { A.2. Processing liquid waste with the } \\
\text { concept of anaerobic pond }\end{array}$ \\
\hline $\begin{array}{l}\text { B. Occupational } \\
\text { Health and }\end{array}$ & $\begin{array}{l}\text { B.1. Using personal protective } \\
\text { equipment (PPE) }\end{array}$ \\
Safety & B.2. Using a smoking cabinet \\
\hline $\begin{array}{l}\text { C. Market } \\
\text { Position and }\end{array}$ & $\begin{array}{l}\text { C.1. Using airtight packaging (vacuum } \\
\text { packaging) }\end{array}$ \\
& $\begin{array}{l}\text { C.2. Expand the marketing area } \\
\text { C.3. Clean water by filtration }\end{array}$ \\
& C.4. Promoting through social media \\
\hline D. Profitability & $\begin{array}{l}\text { D.1. Increasing the economic value of } \\
\text { waste from fresh fish }\end{array}$ \\
& $\begin{array}{l}\text { D.2. Promotion of culinary tourism } \\
\text { D.3. Cooperate with parties involved in } \\
\text { the culinary world }\end{array}$ \\
\hline $\begin{array}{l}\text { E. Long-Term } \\
\text { Risk }\end{array}$ & $\begin{array}{l}\text { E.1. Maintain sanitation and hygiene, } \\
\text { and improve bad habits }\end{array}$ \\
& $\begin{array}{l}\text { E.2. Government reward to fish } \\
\text { processors implementing clean, } \\
\text { healthy, and safe production } \\
\text { process }\end{array}$ \\
& $\begin{array}{l}\text { E.3.Industrialization smoked fish in } \\
\text { Bandarharjo }\end{array}$ \\
\hline
\end{tabular}

Alternative recommendations that have been compared with the existing condition of fish processing then conducted to a feasibility testing to find out how difficult to be applied. The results of the feasibility test are then visualized into a portfolio diagram given in Figure 2.

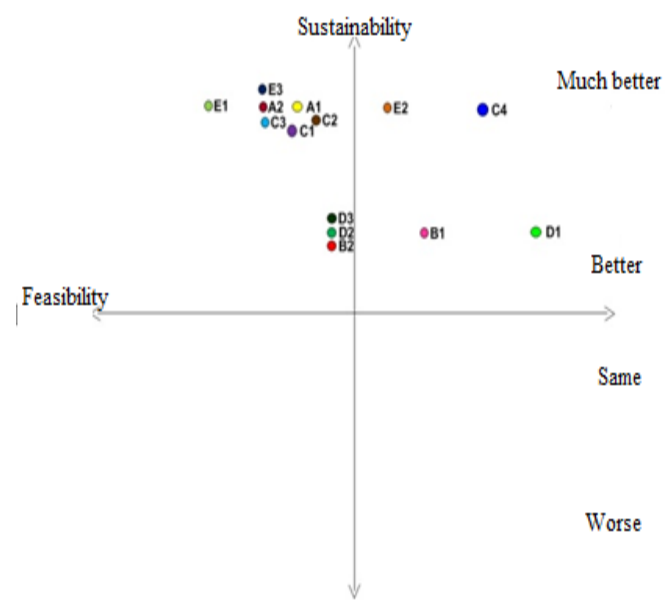

Fig. 2. Portfolio Diagram to map the recommendation 
Figure 2 shows the recommendation at the top right means is the alternative best that can improve the sustainability of the fish processing industries and have the highest possibility to be applied. Some recommendations for fish processing industries are:

- C4 (promoting through social media) and

- D1 (increasing the economic value of product)

- B1 (Using personal protective equipment) and

- E2 (Government reward to fish processors implementing clean, healthy, and safe production process).

The fourth step is to describe the condition and recommendation on a radar diagram for each aspect. The radar for environmental aspect given in Figure 3, the radar for socio-cultural aspect dimension on Figure 4, and the radar for economic aspect on Figure 5.

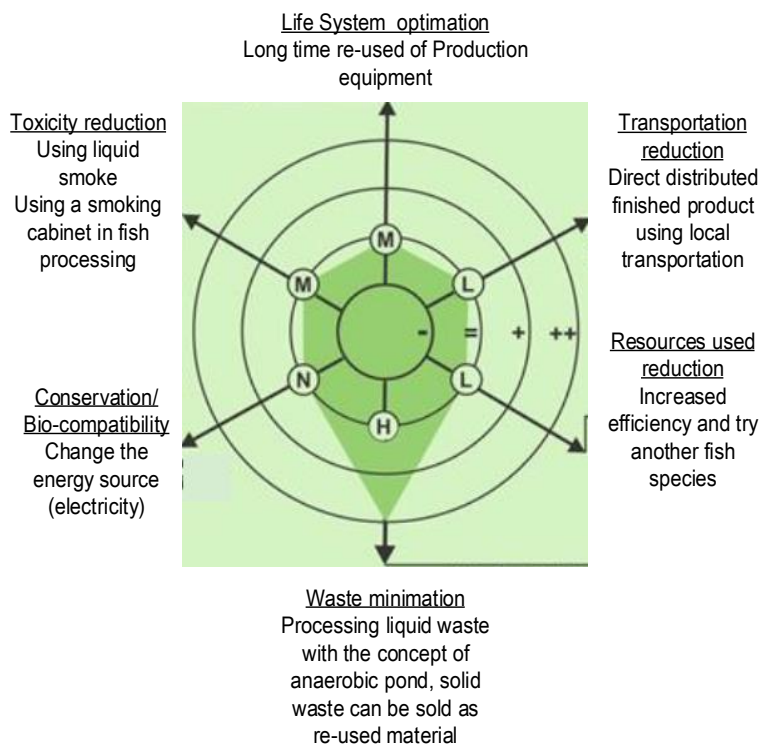

Fig. 3. Radar diagram for environmental dimension

Recommendations for the minimization/waste management criteria suggest the industry to use liquid smoke and installed an equipment of liquid waste treatment with the concept of anaerobic ponds. Liquid smoke has advantages such as easy to apply, smoke concentration can be arranged according to consumer tastes, the product has a uniform appearance and environmentally friendly. Another important point is that liquid smoke not only plays a role in shaping the sensory characteristics but also in terms of food security assurance [18].

Figure 4 is a radar diagram for socio-cultural dimension. Criteria on the high category are Health and Safety, and the recommendation suggests the worker of the industry to using a personal protection equipment. Workers health complaint are on eyes pain and respiratory organ which caused by air pollution. The industries also suggested to using a liquid smoke and smoked cabinet while processing the fish to minimize pollution.

Criteria on a high category on economic dimension are market position and competitiveness, Profitability, and long-term risk. Recommendations for the economic dimension are marketing through social media, and cooperation with supplier and local transportation service provider to distribute the finished product.

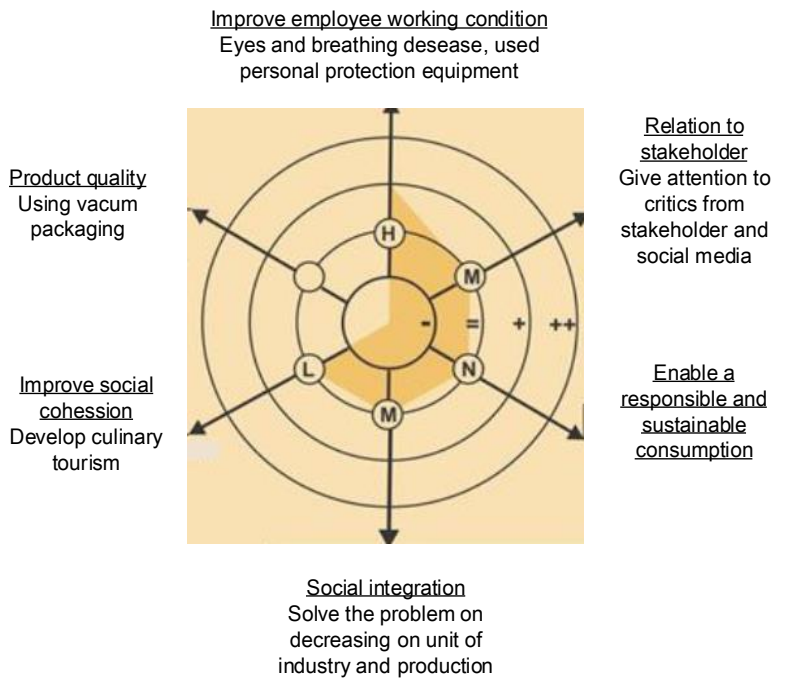

Fig. 4. Radar diagram for socio cultural dimension

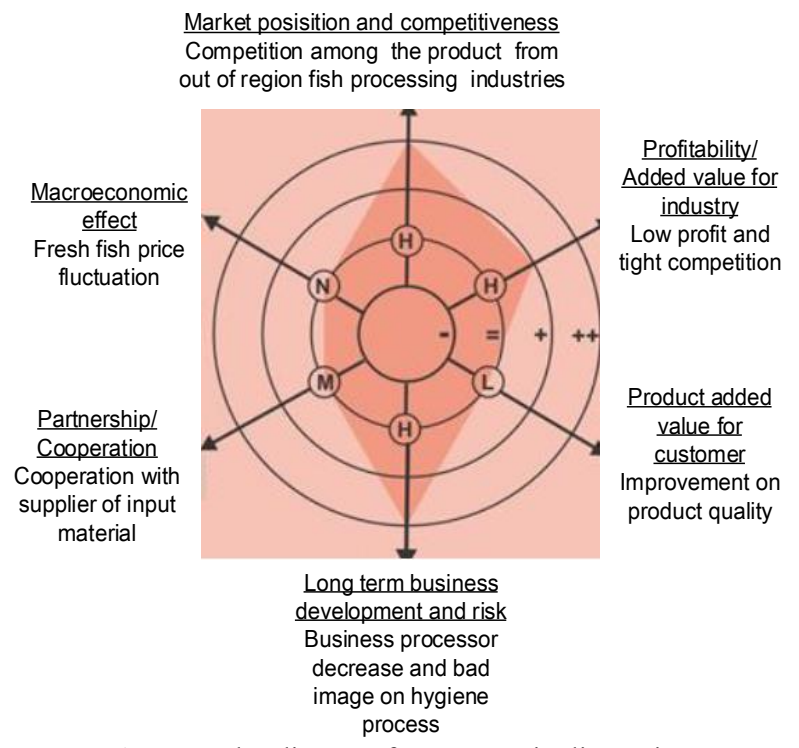

Fig. 5. Radar diagram for Economic dimension

Recommendations to increase profitability is Utilizing fish raw material waste. The smoked fish processors sell back Manyung fish (Arius Thalassinus) lung without further processing, at a price of Rp. 100,000 / kilogram. If it is sold in the form of crackers the price can reach $\mathrm{Rp}$. 250,000 / kilogram.

Recommendations to face long-term risk are creating a reward for an industry which already applied a hygienist production process. The bad image of the production process can cause a threat to sustainability. The fish processors should be able to maintain sanitation and hygiene in the production process and achieve the standard of Good Manufacturing Practices (GMP). Reward in the form of money can be used as an initial motivation. 


\section{Conclusions}

Measurement of sustainability level of traditional smoked fish processing at Semarang gives value 0.44 from $0-1$ scale, included in the medium category. Sustainability criteria that need to be improved are Minimization of Waste, Health and Work Safety, Market Position and Competitiveness, Profitability, and Long-term Risk.

The most feasible recommendations to apply are the use of personal protected equipment for a worker, marketing product through social media, increasing the economic value of waste, and government rewarding for industries implement sustainability in its production process. Waste minimization can be applied by use of liquid smoke and installed liquid waste treatment equipment anaerobic ponds.

\section{References}

1. WCED Our Common Future (The Brundlandt Report). Oxford University Press (1987).

2. M. Crul, J. C. Diehl. Design for Sustainability: A Step by Step Approach. UNEP (2009)

3. T. Mc Aloone, C. and M. Andreasen. Proceedings of the 8th International Design Conference, Dubrovnik, Croatia (2004)

4. K. Haapala, R., K. L. Brown, and J. W. Sutherland. Transactions of NAMRI/SME, 36: 333-340 (2008)

5. E. Moreau, B., B. Tether, Proceeding of DRUID Conference, Copenhagen Business School (2011)

6. T. Palosuo, T. Suominen, W. Werhahn-Mess, J. Gonzalo, G., M. Lindner, Ecological Modelling, 221 pp.2215-2225 (2010)

7. D. Jager,.T., T. Vermeire,.G., W. Slooff, H. Roelfzema, Chemosphere, 29, Issue 2, pp. 319-335 (1994)
8. A. Azapagic, Journal of clean production. 12. 6, pp. 639-662 (2004).

9. Indonesian statistician Bureau. BPS Kota Semarang. (2015).

10. U. Tischner, C. Vezzoli. Module C: Product-Service Systems-Tools and Cases. UNEP. Paris. (2009)

11. Jing Hao. Proceeding of the International Conference on Management Science and Engineering (ICMSE) Sept. 2012, pp 790 - 795 (2012).

12. Geum, Y., Park, Y. (2010). Proceeding of Industrial Engineering and Engineering Management (IEEM) IEEE International Conference, pp 410 - 414 (2010)

13. Wang, Li Ping., Fu Jia Proceeding of Emergency Management and Management Sciences (ICEMMS), 2010, IEEE International Conference, Beijing, pp 126 - 129 (2010)

14. Wangphanich, P Proceeding of Management Science and Industrial Engineering (MSIE) International Conference, pp 554 - 559 (2011)

15. Durugbo, C Concurrent Enterprising (ICE) 17th International Conference, pp 1-8 (2011)

16. Xing, L.Y., Heon Lee, S Service Operations and Logistics and Informatics (SOLI) IEEE International Conference, pp 23 - 28 (2010)

17. R. Purwaningsih, N. Susanto, N. Apsari. Proceeding of International Conference on Electric vehicular Technology and Industrial, Mechanical, electrical, Chemical Engineering (ICEVT \& IMECE) C(5) 1 6 (2015).

18. Swastawati, F. Jurnal Dinamika Ekonomi Pembangunan, 1(1): 18 - 24 (2011) 